\title{
ANALISIS VEGETASI PADA KAWASAN TAHURA LAE KOMBIH KOTA SUBULUSSALAM
}

(Vegetation Analysis in Lae Kombih Forest Park Area Subulussalam City)

\author{
Yuniar Hasanah B Manalu ${ }^{1}$, Ali M Muslih ${ }^{1}$, Ashabul Anhar ${ }^{*}$ \\ ${ }^{1}$ Program Studi Kehutanan, Fakultas Pertanian, Universitas Syiah Kuala \\ *Corresponding author : ashabul.anhar@unsyiah.ac.id
}

\begin{abstract}
Abstrak. Penelitian ini bertujuan untuk mengetahui spesies vegetasi strata semai, pancang, tiang dan pohon yang memiliki peranan paling penting berdasarkan kerapatan. Metode yang digunakan dalam penelitian ini adalah metode analisis vegetasi dengan system random sampling. Analisis vegetasi dilakukan dengan membuat plot sebanyak 5 plot dengan masing-masing plot contoh berukuran $20 \mathrm{~m} \times 20 \mathrm{~m}$, penentuan plot sampling didasarkan kepada informasi pihak Tahura Lae Kombih. Hasil penelitian menunjukkan bahwa di kawasan Tahura Lae Kombih ditemukan sebanyak 127 individu jenis kamper (Dryobalanops aromatica Gaertn) selain itu ditemukan jenis lain yaitu meranti (Shorea spp.), damar (Agathis sp.), rengas (Gluta renghas), akasia (Acacia mangium), gaharu (Aquilaria malaccensis), durian (Durio zibethinus), tongkat ali/ pasak bumi (Eurycoma spp.) dan saninten/rambutan (Castanopsis argentea).
\end{abstract}

Kata kunci : Tahura Lae Kombih, System random sampling, Analisis vegetasi.

\begin{abstract}
This study aims to determine the vegetation species strata of seedlings, saplings, poles and trees that have the most important role based on density. The method used in this research is vegetation analysis method with random sampling system. Vegetation analysis was carried out by plotting 5 plots with each sample plot measuring $20 \mathrm{~m} \times 20 \mathrm{~m}$, the determination of the sampling plot was based on information from Tahura Lae Kombih. The results showed that in the Tahura Lae Kombih area, 127 individuals of camphor (Dryobalanops aromatica Gaertn) were found in addition to other species, namely meranti (Shorea spp.), resin (Agathis sp.), rengas (Gluta renghas), acacia (Acacia mangium), gaharu (Aquilaria malaccensis), durian (Durio zibethinus), tongkat ali/ pasak bumi (Eurycoma spp.) and saninten/ rambutan (Castanopsis argentea).
\end{abstract}

Keywords: Tahura Lae Kombih, System random sampling, Vegetation analysis.

\section{PENDAHULUAN}

Vegetasi dapat didefinisikan sebagai kumpulan dari beberapa jenis tumbuhan yang tumbuh secara bersamaan pada satu kawasan. Sebagai contoh vegetasi secara umum akan mengurangi laju erosi tanah, tetapi besarnya tergantung pada struktur dan komposisi tumbuhan yang menyusun formasi vegetasi daerah tersebut. Data yang diperoleh nantinya akan berupa gambaran tentang kondisi lapangan yang dianalisis kedalam bentuk angka untuk menyatakan kondisi lingkungan.

Analisis vegetasi merupakan cara untuk mengetahui besar sebaran dari berbagai spesies dalam suatu kawasan yang dilakukan melalui pengamatan secara langsung. Analisis vegetasi dilakukan dengan membuat plot, mengamati morfologi dan identifikasi vegetasi yang terdapat dilapangan. Beberapa parameter yang dapat dihitung dalam kegiatan analisis vegetasi yaitu kerapatan mutlak, kerapatan relatif, frekuensi mutlak, frekuensi relatif, dominasi mutlak, dominasi relatif dan indeks nilai penting (Sari et al., 2018). Komposisi vegetasi pada suatu kawasan dipengaruhi oleh komponen ekosistem yang saling bersangkutan, sehingga vegetasi yang tumbuh baik secara alami pada suatu kawasan merupakan hasil dari interaksi berbagai faktor lingkungan. Dalam rangka mengetahui jenis dominan yang tumbuh dilokasi tersebut maka perlu dilakukan suatu penelitian terkait analisi vegetasi. 
Tahura Lae Kombih adalah salah kawasan pelestarian alam yang berada di Kota Subulussalam. Tahura Lae Kombih memiliki tanaman endemik yaitu Dryobalanops aromatica Gaertn. yang berada dibawah pengawasan Dinas Lingkungan Hidup dan Kehutanan (DLHK) dengan tujuan melestarikan Dryobalanops aromatica Gaertn. Kabupaten Aceh Singkil menetapkan kawasan Kedabuhen, Desa Jontor, Kecamatan Penanggalan menjadi kawasan konservasi Cagar Alam Dryobalanops aromatica Gaertn. Sejak pemekaran menjadi daerah otonomi pemerintah kota Subulussalam menggagas peningkatan pengelolaan kawasan konservasi Dryobalanops aromatica Gaertn. menjadi kawasan konservasi baru sebagai kawasan konservasi Taman Hutan Raya Lae Kombih dengan luas areal 1.482 ha sesuai SK Menteri Lingkungan Hidup dan Kehutanan Nomor SK.510/MenLHK/Setjen/PLA.2/9/2017.

\section{METODE PENELITIAN}

\section{Alat dan Objek Penelitian}

Penelitian ini mengunakan alat yaitu Hypsometer (untuk mengukur ketinggian pohon), GPS, meteran, kamera dan alat tulis. Adapun objek yang akan diamati yaitu jenis tanaman kehutanan pada fase pertumbuhan semai, pancang, tiang dan pohon di kawasan Tahura Lae Kombih Kota Subulussalam Provinsi Aceh.

\section{Metode Penelitian}

Penelitian ini menggunakan metode analisis vegetasi dengan system random sampling (Soerianegara and Indrawan, 2005). Analisis vegetasi dilakukan dengan membuat plot sebanyak 5 plot, masing-masing plot contoh berukuran $20 \mathrm{~m}$ x $20 \mathrm{~m}$, penentuan plot sampling didasarkan kepada informasi pihak Tahura Lae Kombih terkait keberadaan jenis Kamper tersebut.

\section{HASIL DAN PEMBAHASAN}

\section{Analisis Vegetasi}

Hasil penelitian menunjukkan di kawasan Tahura Lae Kombih Kota Subulussalam, ditemukan jenis tumbuhan mulai dari tingkat semai, pancang, tiang dan pohon. Tumbuhan yang ditemukan di kawasan Tahura Lae Kombih Kota Subulussalam sebanyak 9 jenis dengan total jumlah seluruh jenis 144 individu yang tersebar pada 5 plot pengamatan. Berdasarkan hasil penelitian, keempat fase pertumbuhan tersebut yang paling banyak ditemukan pada tingkat pohon 34\%, hal ini disebabkan karena pohon kamper merupakan salah satu tanaman yang masuk kedalam kelompok tumbuhan toleran (kemampuan pohon yang dapat tumbuh dengan baik dibawah naungan), tingkat semai 33\%, tingkat pancang $19 \%$ dan tingkat tiang 13\%. Penelitian dengan metode serupa juga dilakukan oleh Sugianto et al. (2021) di Suaka Margasatwa Rawa Singkil yang menunjukan terdapat 25 jenis tumbuhan yang terdiri dari 3 fase pertumbuhan yaitu pancang, tiang dan pohon. Berdasarkan penelitian yang dilakukan Muslih et al. (2021), sistem agroforestri yang diterapkan petani dengan memadukan komoditas kehutanan dan pertanian dalam pemeliharaan lebah. Cara ini lebih disukai petani karena merasa lebih 
mendapatkan manfaat yang optimal. Sistem pemeliharaan lebah adalah sistem agroforestri yang menggabungkan kegiatan kehutanan dengan lebah.

Tabel 1. Spesies tumbuhan di kawasan Tahura Lae Kombih Kota Subulussalam

\begin{tabular}{clll}
\hline No. & Nama Daerah & \multicolumn{1}{c}{ Nama Ilmiah } & Famili \\
\hline 1. & Kamper & Dryobalanops aromatica Gaertn. & Dipterocarpaceae \\
2. & Gaharu & Aquilaria malaccensis & Araucariaceae \\
3. & Damar & Agathis sp. & Anacardiaceae \\
4. & Rengas & Gluta renghas & Fabaceae \\
5. & Akasia & Acacia mangium & Fagaceae \\
6. & Saninten/ Rambutan hutan & Castanopsis argentea & Bombacaceae \\
7. & Durian & Durio zibethinus & Dipterocarpaceae \\
8. & Meranti & Shorea spp. & Simaroubaceae \\
9. & Tongkat Ali/ Pasak Bumi & Eurycoma spp. & \\
\hline
\end{tabular}

\section{Komposisi Jenis}

Komposisi jenis merupakan faktor penyusun suatu ekosistem yang terdiri dari beberapa kumpulan vegetasi. Berdasarkan Tabel 2. jenis vegetasi yang lebih dominan ditemukan pada tingkat pohon sebanyak 49 individu dan yang paling rendah ditemukan pada tingkat tiang sebanyak 19 individu. Jenis yang paling dominan pada kawasan ini yaitu Dryobalanops aromatica Gaertn. dengan total 127 individu atau setara dengan $88 \%$ dari total keseluruhan. Jenis Dryobalanops aromatica Gaertn. memiliki individu paling banyak dari jenis lain karena Tahura Lae Kombih adalah kawasan yang bertujuan untuk melestarikan Dryobalanops aromatica Gaertn., dari segi tingkatan, jumlah individu Dryobalanops aromatica Gaertn. paling banyak dijumpai yaitu pada tingkat semai dan pohon sedangkan yang paling sedikit yaitu pada tingkat tiang dan pancang, hal ini dapat dipengaruhi oleh kecepatan angin, kelembaban udara dan penurunan suhu. Salah satu faktor penting yang dapat mempengaruhi pertumbuhan dari semai menjadi pohon dewasa adalah cahaya matahari, cahaya matahari merupakan kunci berlangsungnya proses metabolisme didalam tanaman, karena pohon kamper merupakan tanaman toleran proses berlangsungnya fotosintesis kurang optimal yang mengakibatkan pertumbuhan tingkat pancang dan tiang lambat.

Faktor kedua yang dapat mempengaruhi terhambatnya pertumbuhan pohon kamper adalah jarak tanam. Jarak tanam yang lebar akan memicu peluang pertumbuhan tinggi lebih besar, fakta dilapangan menunjukkan pertumbuhan semai yang rapat mengakibatkan sulitnya semai untuk tumbuh menjadi pancang dan seterusnya.

Berdasarkan pengamatan dilapangan Tahura Lae Kombih termasuk kategori hutan sekunder, terbukti pada saat penelitian jumlah individu pohon kamper lebih dominan dengan keadaan pohon yang rata-rata sudah tua, bergerowong dan ditebang. Karena umur pohon kamper yang sudah tua dan tumbuh di tepi lintas jalan, pohon tumbang sangat sering terjadi yang mengakibatkan hilangnya indukan pohon dan memperlambat proses regenerasi kembali.

Tabel 2. Komposisi jenis yang ditemukan di kawasan Tahura Lae Kombih Kota Subulussalam berdasarkan tingkatan

\begin{tabular}{|c|c|c|c|c|c|c|c|}
\hline \multirow{2}{*}{ No. } & \multirow{2}{*}{$\begin{array}{l}\text { Nama } \\
\text { Pohon }\end{array}$} & \multirow{2}{*}{ Nama Ilmiah } & \multicolumn{5}{|c|}{ Fase Pertumbuhan } \\
\hline & & & Semai & Pancang & Tiang & Pohon & $\%$ \\
\hline 1. & Kamper & $\begin{array}{l}\text { Dryobalanops } \\
\text { aromatic }\end{array}$ & 47 & 23 & 17 & 40 & 88 \\
\hline 2. & Gaharu & Aquilaria malaccensis & - & - & - & 1 & 0,6 \\
\hline 3. & Damar & Agathis sp. & - & - & - & 2 & 1,4 \\
\hline
\end{tabular}




\begin{tabular}{|c|c|c|c|c|c|c|c|}
\hline 4. & Meranti & Shorea spp. & - & - & - & 5 & 3,4 \\
\hline 5. & Rengas & Gluta renghas & - & - & - & 1 & 0,6 \\
\hline 6. & Akasia & Acacia mangium & - & 3 & - & - & 2,1 \\
\hline 7. & Durian & Durio zibethinus & - & - & 2 & - & 1,4 \\
\hline \multirow{3}{*}{$\begin{array}{l}8 . \\
9 .\end{array}$} & Saninten & Castanopsis argentea & 1 & 1 & - & - & 1,4 \\
\hline & $\begin{array}{l}\text { Pasak } \\
\text { Bumi }\end{array}$ & Eurycoma spp. & - & 1 & - & - & 0,6 \\
\hline & Total & & 48 & 28 & 19 & 49 & 100 \\
\hline
\end{tabular}

\section{KESIMPULAN DAN SARAN}

Jenis tumbuhan yang ditemukan berdasarkan penelitian di kawasan Tahura Lae Kombih Kota Subulussalam yaitu 9 jenis tumbuhan dengan total jumlah seluruh jenis yaitu 144 individu yang tersebar pada 5 plot pengamatan. Persentase fase tingkat pertumbuhan dari jenis yang ditemukan adalah tumbuhan pada tingkat pohon $34 \%$, tingkat semai 33\%, tingkat pancang 19\% dan tingkat tiang $13 \%$. Hasil penelitian menunjukkan bahwa di kawasan Tahura Lae Kombih ditemukan sebanyak 127 individu jenis kamper (Dryobalanops aromatica Gaertn) selain itu ditemukan jenis lain yaitu meranti (Shorea spp.), damar (Agathis sp.), rengas (Gluta renghas), akasia (Acacia mangium), gaharu (Aquilaria malaccensis), durian (Durio zibethinus), jabon putih (Anthochepalus cadamba), tongkat ali/ pasak bumi (Eurycoma spp.) dan saninten/ rambutan (Castanopsis argentea).

\section{DAFTAR PUSTAKA}

Muslih, A.M., Bintoro, A., Duryat, Subhan, Arlita, T., Ar Rasyid, U.H., Umam, A.H., Farida, A. and Yanti, L.A., 2021. The study of silvicultural aspects of community forest in Buana Sakti Lampung Province. IOP Conf. Series: Earth and Environmental, 667012053.

Soegianto, A., 1994. Ekologi Kuantitatif : Metode Analisis Populasi dan Komunitas. Surabaya: Usaha Nasional.

Sugianto, S., Muslih, A.M., Ar-Rasyid, U.H. and Anhar, A., 2021. Analisis Vegetasi Suaka Margasatwa Rawa Singkil di Rantau Gedang Desa, Kecamatan Singkil, Kabupaten Aceh Singkil, Provinsi Aceh. IOP Conf. Series: Earth and Environmental Science, 667012068.

Soerianegara and Indrawan, 2015. Ekologi Hutan Indonesia. Laboratorium Ekologi Hutan. Fakultas Kehutanan, Bogor: Institut Pertanian Bogor.

Sari, D.N., Wijaya, F., Mardana, M.A., and Hidayat, M., 2018. Analisis Vegetasi Tumbuhan Dengan Metode Transek (Line Transect) Dikawasan Hutan Deudap Pulo Aceh Kabupaten Aceh Besar. Prosiding Seminar Nasional Biotik 2018. 